\title{
A CASE OF MALIGNANT HISTIOCYTOSIS ARISING IN THE LARYNX
}

\author{
YASUO WATANABE, M. D. AND KANZI MUTO, M. D. \\ ENT-clinic, Osaka Prefectural Hospital \\ KATSUYUKI AOZASA, M. D. \\ Department of Pathology, Osaka University Medical School
}

(Director: K. Matsumoto M. D.)

This paper reported a case of malignant histiocytosis with laryngeal involvement as an initial sign.

A male, aged 37, who developed hoarseness and nasal obstruction in November, 1976, and visited us on April 8, 1977.

On examination, there were granulomatous changes in the right arytenoid area and the false cord, and inflammation of the oropharynx. Repeated biopsies of the lesion, however, showed inflammatory changes only. The patient continued a chronic course unresponsive to antibiotics and steroids.

In February, 1978, he became febrile and developed granulomatous changes extending to the aryepiglottic fold and epiglottis, and right side of the latter became necrotic and ulcerative. Radiotherapy was initiated and dramatic regression of the lesion was seen. One month later, the patient developed a painful swelling on the left nasal wing, which was biopsied and diagnosed as malignant lymphoma (histiocytic type)

Radiationtherapy was again instituted and 2800 rads was given with dramatic improvement. Two months later, he developed red crusted subcutaneous nodules of about $2 \mathrm{~cm}$ in diameter on the chest, back and both thighs.

Biopsy of the nodule on the chest revealed infiltration of atypical histiocytes. Further biopsies showed findings more compatible with malignant histiocytosis.

In October, 1978, he became icteric, febrile and leucopenic, and bleeding from the oropharynx was seen. He died of profuse bleeding from the oropharynx after 2 years from the onset of the disease. Autopsy was not obtained.

The characteristics of malignant histiocytosis in the upper respiratory tract (especially nose) are follows:

1) The initial lesion is seen at non-lymphnode bearing areas.

2) Localized and generalized lymphadenopathy and splenic enlargement are uncommon.

3) The histological features observed in the initial lesion usually polymorphic cell infiltration accompanied by lymphocytes, plasma cells and histiocytes. The degree of histiocyte proliferation is in the spectrum of several cells in a high power field to an almost monotonous pattern. In the monotonous proliferation, histiocytic cells show lack of cohesiveness. The erythrophagocytosis is also seen.

4) The specific esterase activity by $\alpha$-Naphthyl-acetate method is observed in the atypical cells. 


\section{喉頭に発症した malignant histiocytosis $の 1$ 例}

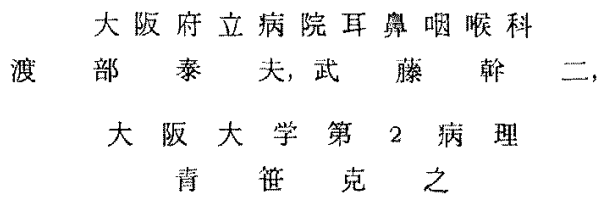

はじめに

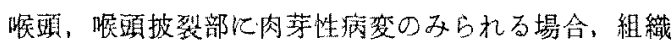
診により診断され難いことは稀である。これは唉頭にみ

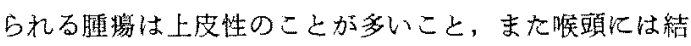

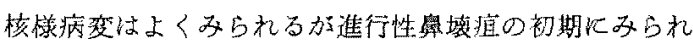
るような non specific な资症が少ないこと化ある。

今回私どもは喉頭任発症した肉芽性病变が泍次進展し 組織の填死をきたし，次いで學部扰上び胸部・四肢の皮 下に結節性病変がみられ発症後約 2 年で兴疸, 出血々上 り死亡した症例を経験した，本症例の初期の病変の組織

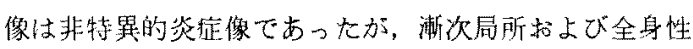
飞 atypical histiocyte の增殖による腫篦が出現した。

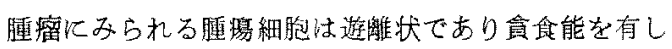
esterase 活性を認め，リンパ球系睡覆にはみられない特 徵がみられた.

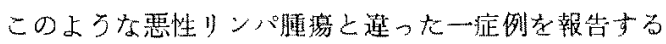
ととも臨床像, 組織像より malignant histiocytosis 2

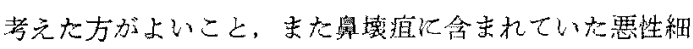
絧症の病愳類似性があるのでこの点についても教察を 加之た.

症例 37 㭰里子 笠靴業

初診 昭和 52 年 4 月 8 日

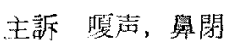

家族歷 特記すべきこと机し

晓往歴 昭和51年6月 外管(ゴルフのクラブが下顛

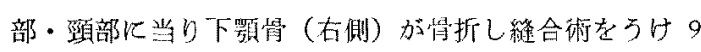
月鎆線を抜去).

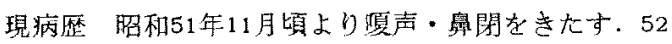
年 2 月末より口内炎ができる。52年 4 月 8 日 当科任积 介される。

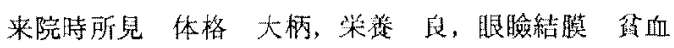
（一）黄染(一), 対孔反射正常
胸部理学所見買常老認好ない，腹部，四肢化も異常 認めない。

局所所見雨下舅甲介は浮腄状に腫脹, 咽頭は全体に 著しく発赤，声带は阔声带とも発亦浮腫状で左側はポリ 一ブ様儿腄脤，右側は披裂部近く亿肉芽形成を認める。 経週 (1)

抗生物質(バストシリン，ケフレックス）等投与した が，軟口蓋，口蓋垂中心の喁頍の所見は漸次悪化し小

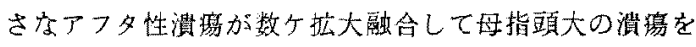
形成与る，周辺は発赤む强く，疼痛の培无も著しい，ᄂ

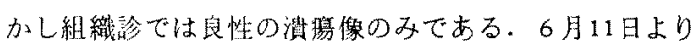
リンデロン4錠/日 投与するが殆えど効果を認めない。 6月20日より，ガンマグロブリン 2.5gr 4 日間静注する がこ机にても改善なく，7月になり咽頭の他に右下甲介

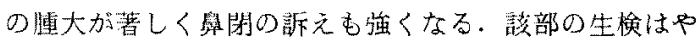
はり非特異的资症像であった７月18日ソルコーテフ $800 \mathrm{mg} /$ 日静注 2 日間，その後リンデロン投与を行なろ が改善なく9月になりガンマベニン注を再度行なうが㩖 閉，望声いずれも改善しない，口腔粘膜病变のみ消長を 繰り返す。

9 月 7 日入院, ハイドロコートン $100 \mathrm{mg} /$ 日 バス卜 シリン（1，0/日）インダシン 3 ケ/日を投与する.9月

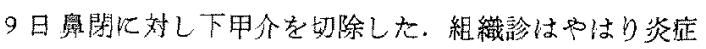
像であった.9月17日よりデカドロン $4 \mathrm{mg}$ 朝夕3 日間 投与した.下甲介切除授骨閉は改善, 咽頭の痛みもとれ 調子がよくなる，その後も全身状隹怯比胶的よかった。 10月14日 涙頭所見改善しないため, プレドニン2錠/日 エンドキサン 2 錠/日投与する。㬋頭の肉芽性病变は改 善しないが鱟閉が少し部改普した。

経過 (2)

12月12日よりプレドニン 3 錠/隔日にて投与していた

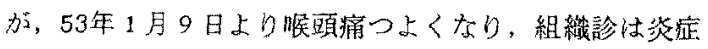




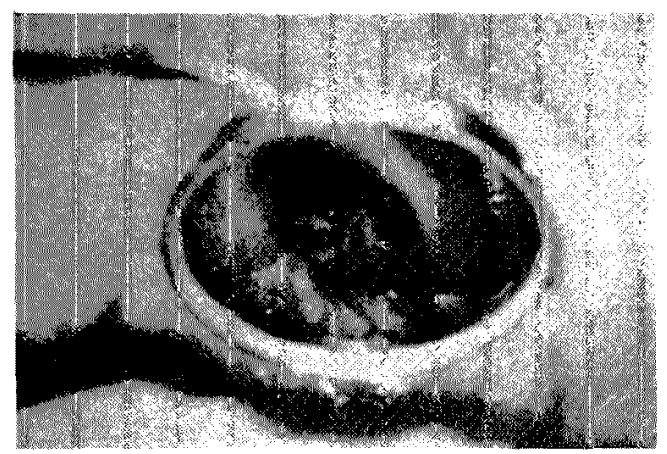

写真 1 喉頭鏡所見 (1)

披裂部(右) O肉契班成 $(53 ， 2)$
であるが経過より瑟性腫獾も否起できないので，PSK

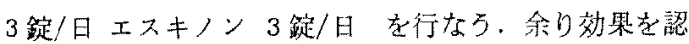
めず。1月28日再入院する。1月29日より副简皮質ホル モン（リンデロン6踶/日) 齐開始した。この頃より $38^{\circ} \mathrm{C} \sim 39^{\circ} \mathrm{C}$ 婯後の発熱老さたす，53年 2 月 9 日，喉頭

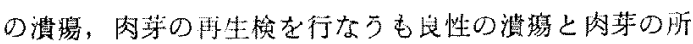

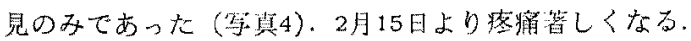
2月16日よりデカドロン $4 \mathrm{mg}, 8 \mathrm{mg} /$ 日 と增量し, 疼

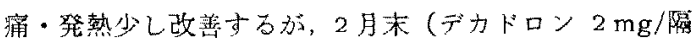
日に隇量すると1週目より) 再び疼痛が強くなり, 発 熱 $\left(39.5^{\circ} \mathrm{C}\right)$ がみられた。咽䫓痛著明で経口抵取下能の ため3月2日上り胃チュープ聥入する。3月6日テ力

表 1

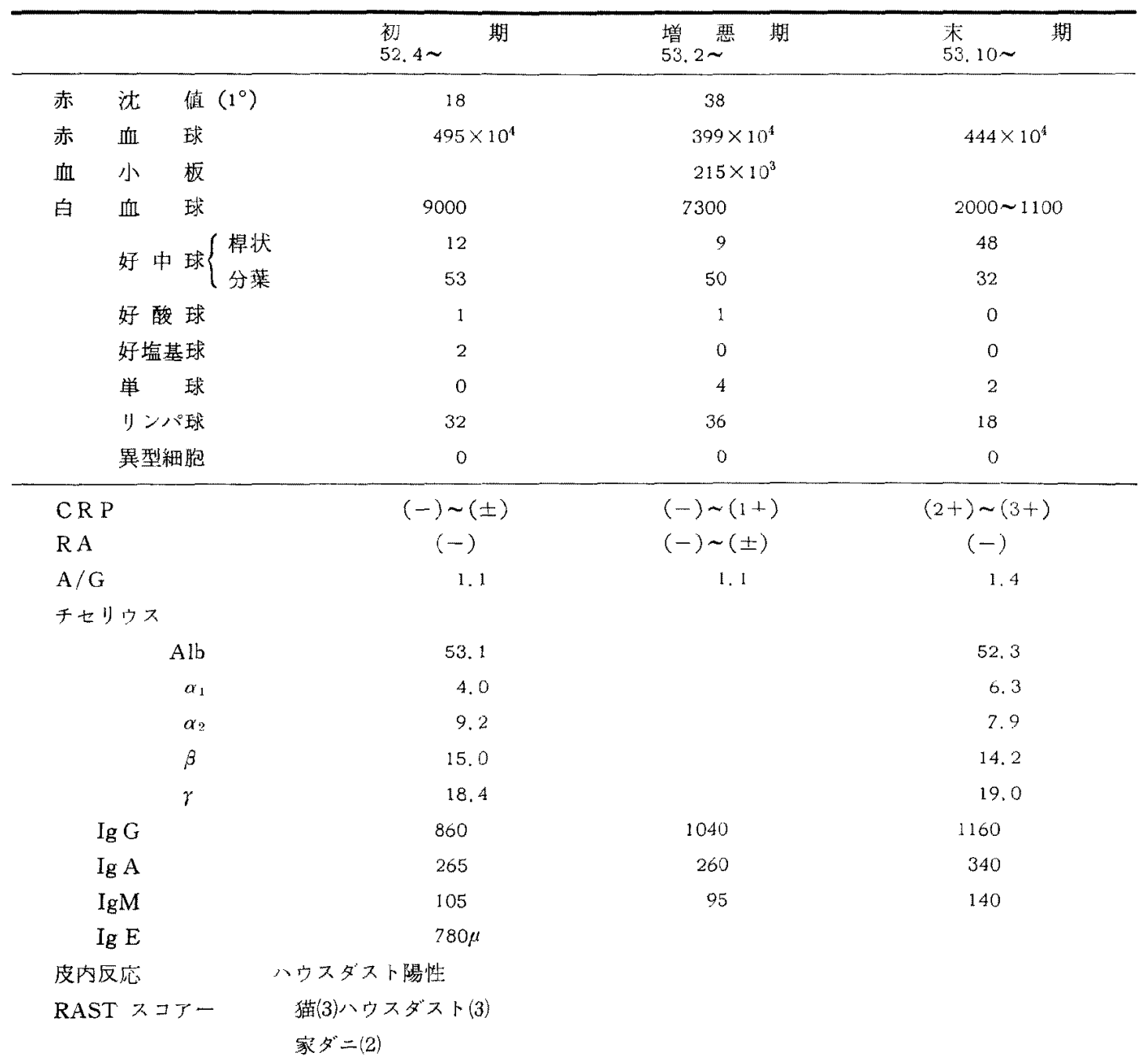


ツ区応

GOT

GP T

$\mathrm{LDH}$

Al-P

Coombs 試駼

$\mathrm{Au}$ 抗原

Paul-Bunnell

Middlebrook Dubos

Widal

Weil Felix

トキソプラスマ

ライシュマニナ

骨髄穿刺

組織晾

尿 $\left\{\begin{array}{c}\text { 蛋白 } \\ \text { 糖 }\end{array}\right.$

P S P (15分)

(30分)

WR

結核菌

一般細菌検查
$65 \times 37$

11

19

540

9

17

555

50

466

4. 6

14.7

20.8

$(-)$

$(-)$

$1: 64$

$1: 32$

$(-)$

$(-)$

$1: 512$

認めない

簧型細胞 $(-) \rightarrow(+)$

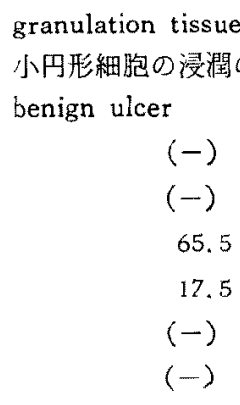

$(-)$

Pseudomonas

aeruginosa

3 月

$\alpha$-type streptococcus

酥母样真菌

Neisseria

Streptococcus

5月 aureus

(鼻) Serratia

marcescens
ドロン $2 \mathrm{mg} /$ 日注メドロール6錠 $(24 \mathrm{mg}) / \mathrm{H}$ 内服 ソ ルコーテフ $300 \mathrm{mg} /$ 日 (7 日間) $200 \mathrm{mg} /$ 日 (19日閐) 使用する。発熱は副腎皮質ホルモン剂使用で少しは改善 する。

4 月 4 日より リンデロン $1 \mathrm{~A}(2.5 \mathrm{mg}) 4$ 月11日より

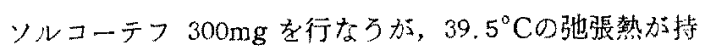

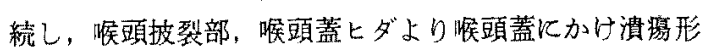
成，喉頭蓋の 発赫腫脤，喉頙蓋の右側の罗死に上る消

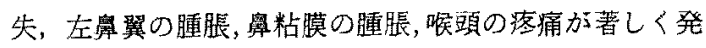
熱も持続するようになり副筒皮筫ホルモン剂の効果に限

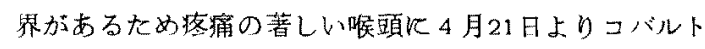
炤射を行な弓．效果は著しくコバルト $2300 r$ で愁訴は 消失，喉頭の填死の准行も停止した５月左鼻翼が発赤 腫脹し，生侻を行なったとこる histiocyticな malignant lymphoma との結果が得られた（写真 5,6 ).この部の 疼痛も著しいため該部にもコバルト照射 $(2800 \mathrm{r}$ )を行 ない, 适脹, 疼痛改善した. malignant reticulosis え6月26日より多威代用療法 (COP) を行ない, 発熱, 疼痛消失，一応寛解状態にあったのて7月29日退院し た。 


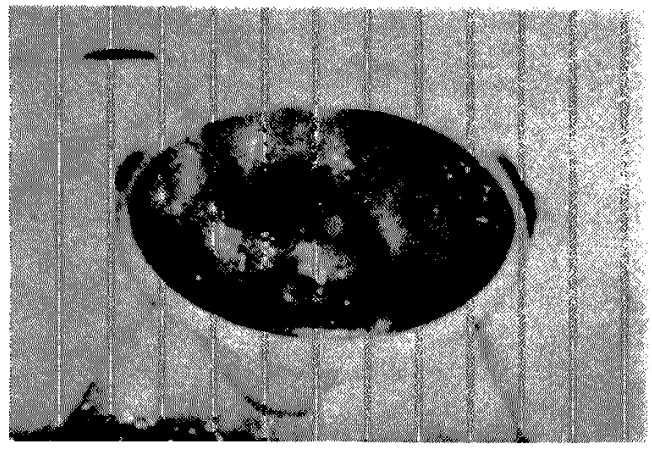

写真 2 喉頭鏡所見 (2)

2 力月後 (53.4.22) の喉頭蓄の1部欠損打 よひ呢頭蓋谷の漬境形成

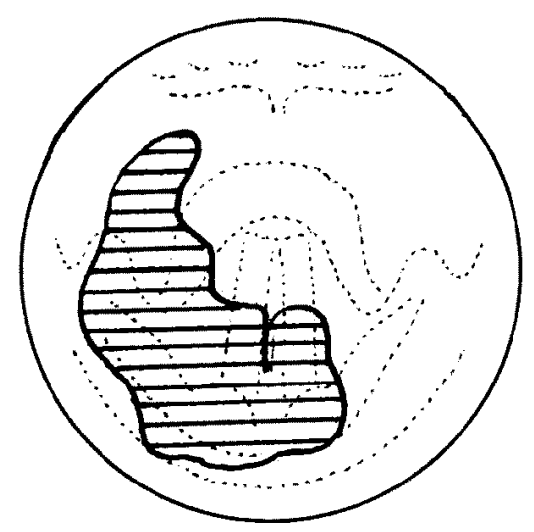

图 1 喉頭病変の㹡がり

释過 (3)

8月1日頃, 㫣頭部の先端に小指頭大の肉芽形成を認 め抗生物質を投与したが効果なく，生検を行なったが non specific granulation であった。

その頃，前胸壁，背部皮下に指指大の結節を生し た. 10月3日前胸壁の結節の生䐿にて malignant reticulosis と診断された（写真 7 ).

同様の結筑は右大腿部, 左大腿部, 慰部にあみられた。 10月12日，骨铕の生検を行なったが腫瑝性の細胞は㒛 められなかった。

同日より発熱持続, 咽頭の槕場も拡大悪化した. 白血 球数は $4100, \mathrm{LDH} 130$ であったが, 以後白血球の減少 傾向がみられ，11月13日には白血球数 2000, CRP $2+$ となる、以後10日間患者は来院しなかった。

11月22日，咽頭痛激化し自宅にてインダシン坐薬を使

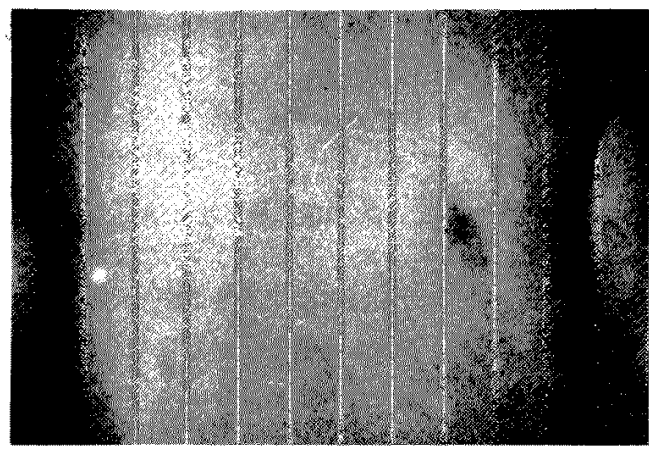

写真 3

背部皮下（右側）に認められた発赤を半った soft tissue mass. (発症 1 年 9 力月後)

用し血圧低下, 体温低下のショック状態となり㢣急再入 院した、咽頭の発赤, 括よび多発性溑場所見昰化を認め た、副㡂皮質ホルモン剂(ソルコーテフ $300 \mathrm{mg}$, デカ ドロン $4 \mathrm{mg}$ ) 詁よむガンマベニン $500 \mathrm{mg}$ を 3 日閒投 与する。11月25日夜より腹痛, 腹部膨渵感が著しくなり Ileus が疑われたが熱気にて排便あり翌日腹部膨泗感は 改善した。しかし11月27日，咽頭上部より出血著しく電 気数固定行なった，白血球数 1400.11月28日 再び口腔 内に大量出血をきたし, 右肺の㳫下性肺资扣よび肝腫大 を認め大. GOT, GPT いずれも 500以上. LDH 466 と上昇11月29日死亡した。

\section{考按}

耳累咽喉科領域の疾患は比較的生㛟し易く従って組織 診が重要な役割を果す場合が多い。しかしながら一部の 疾患では組織診がはっきりしない場合がある。

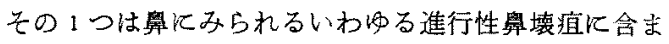

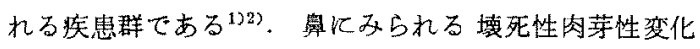
○組織診は姿々非特異的炎症像で鑑別㟝断がでさい場 合があるが).

この場合やがて病变が進行し 全身性の症状がでて，

Wegener 肉芽腫，あるいは悪性細䋛症などと診断され る. その中でも悪性細䌁症は一般検査成績にも变化が少 なく山現する atypical monocyte は分散しており reactive と孝光台れ彰断が難しい。

喉頭の悪性疾患としては瘦が多く ${ }^{6\rangle}$ 間葉系の悪性腫瘍

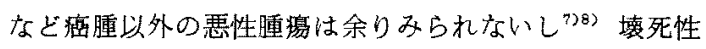

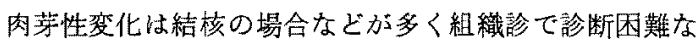
症例は䅦である。 

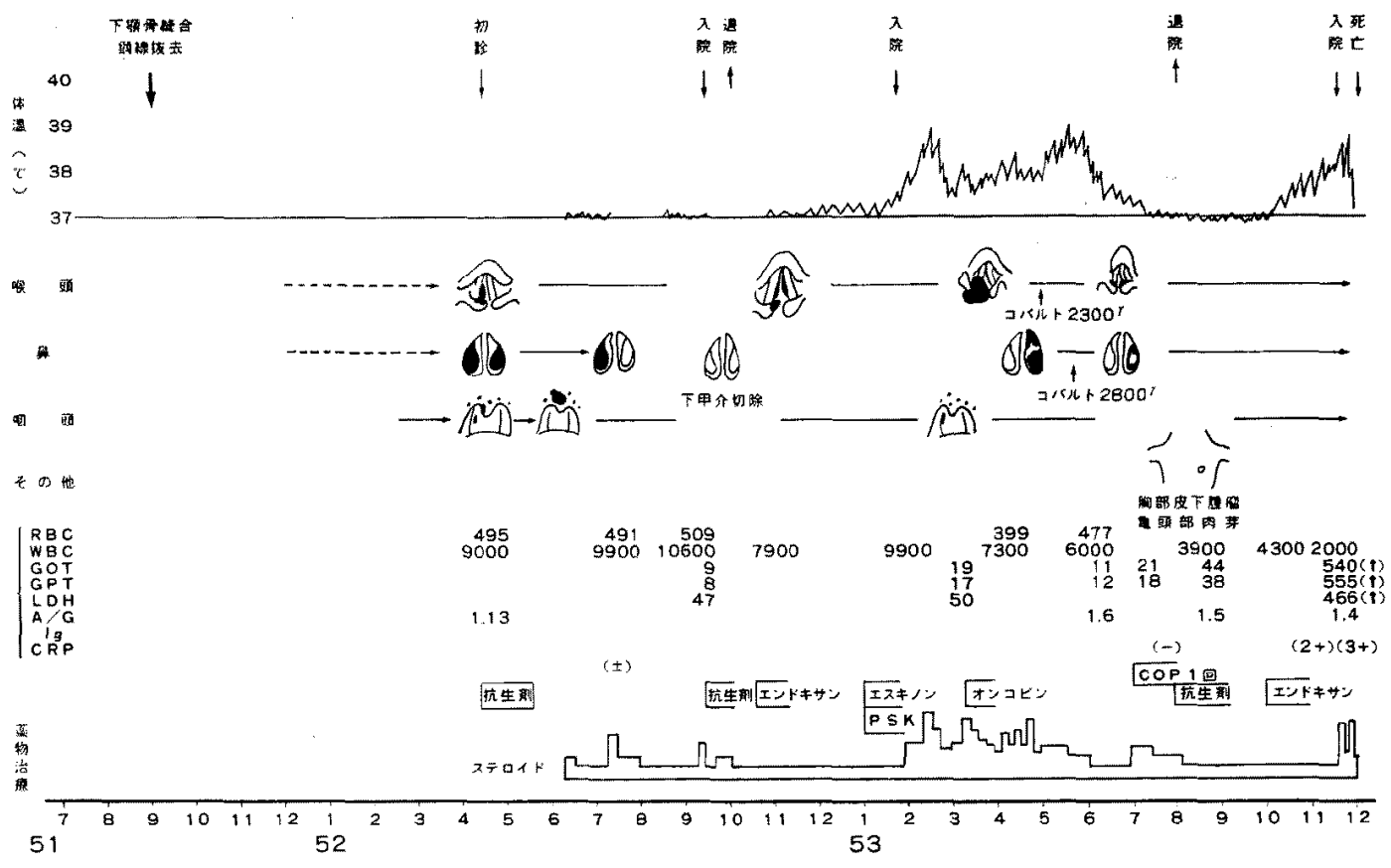

図 2

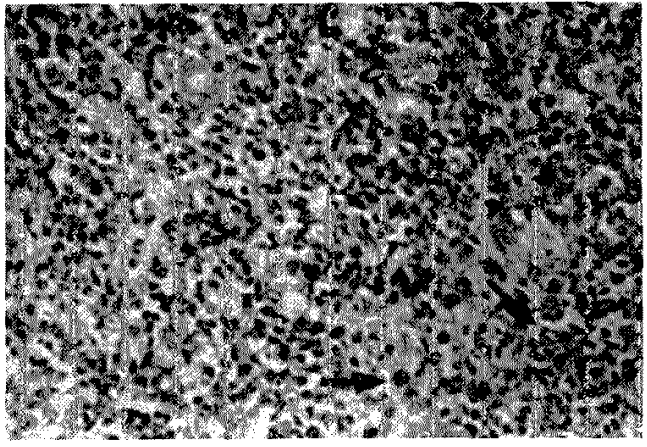

写真 4 上気道の壊死性肉芽

リンパ球, 形啠細胞汇混じて少数の大型組織 球（矢印）をみるが，この段階では腫滨性格は 明らかでない。

今回報告した症例は榎声と綥閉を初期症状とし，その 後, 咽頭, 軟口蓋に病変をみとめた.

初期の生㛟で注いずれも暃特買的度所見しか得られず 診断がつかぬまま少量の副腎皮質ホルモン刘を中心の治

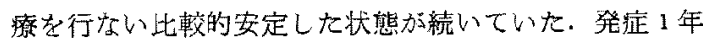
4 力月後まず喉頭の肉芽性病变加披裂喉頚蓝ひだ，㘈頭

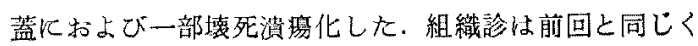

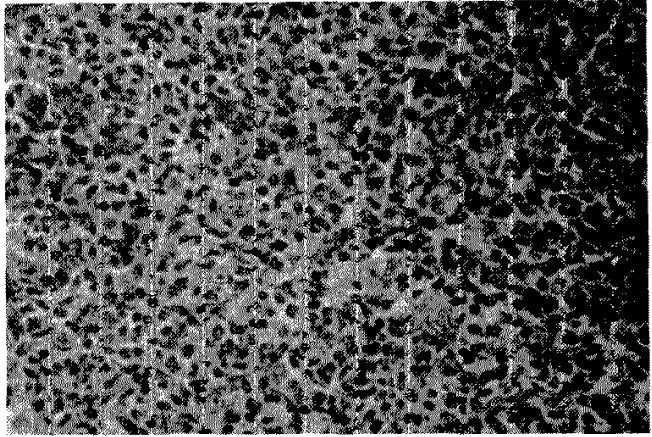

写真 53 力月後の生検像 (上気道)

写真 4 と異なり大型の異型組織球の增殖が著 明であり腫宪性格が明らかである。

非特異的炎症であったが，墨性腫瘍を予想し化学療法 （エンドキサン，オンコビン，副珡皮質ホルモン）を試 みたが殆几ど効果なく病变讨進展した。

背下痛が著しくなり薬物治療飞も反応しないため放射 線照射を行なったところ，1000r 位で著しく効果あり， 2300rで啹頭の病变は一部欠損を残し寛解した。しかし 半月後舆病変加進行し，この部位の生検で malignant 


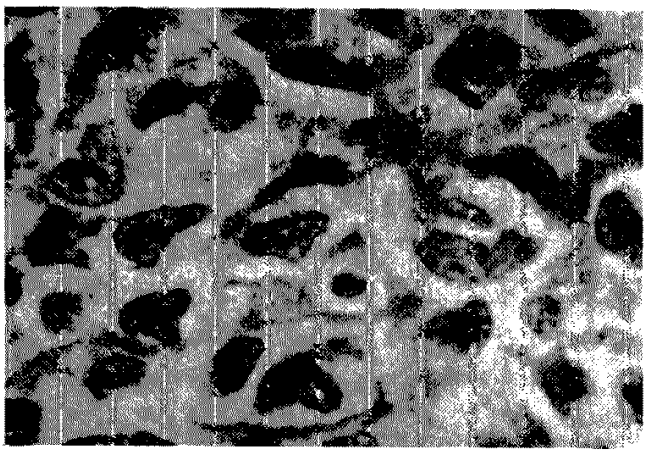

写真 6 5. の拡大像

好酸性の豊富な細胞質を有し、一ケの大型な 核小体がみられる，校縁は不整である。

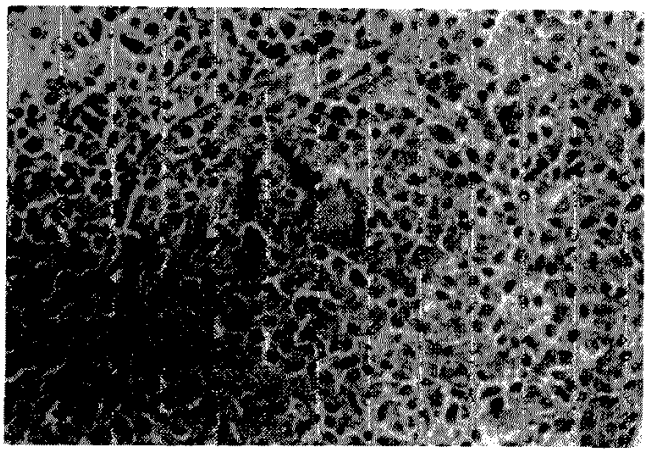

写鼓 7

8 力月後，腹䇒皮下代形成された腫瘤、組織 球性細胞のみであり，中心部に 2 ケの多核巨細 胞をみとめる。

lymphoma (histiocytic type) と診断された。算病变に

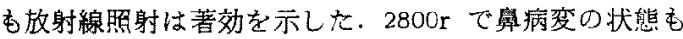
安定した，搌頭および舅病窡はその後末期まで安定した 状態が続いた。

しかし発症 1 年10力月日前脑壁，背部および大腿部

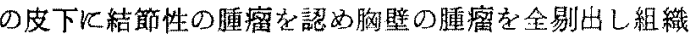
を調べたところ，遊咘隹した atypical な histiocyte の增 殖を認め本症例を malignant histiocytosis と診断した。

しかし同じ頃発生した䚣頭部の肉芽性病変の組織診は 㗹頭病变と同様に非特異的で抗生都に反応しない特殊な 肉芽であった。

剖検は許されなかったが末期の血球隇少，黄疸，相 機能低下などの病態はいずれす histiocyteの各㬝器への 浸潤の結果と思加れる。

本症例の病態の特徽は初期の非特買的な内芽形成にあ
りこの病態は一定期間の後, 菬聺形成, 㯖死化に進展し た。しかしその部位よりは悪性所見や結核菌のような特

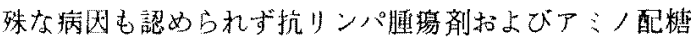
体にも反応しなか力大。

奥病変で malignant lymphoma $\sigma$ histiocytic type が諗められたが，この場合も初期（確定鉁の8および10 力月前）の組織彰では非特異的であった。

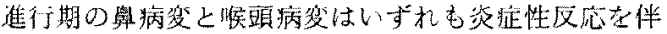

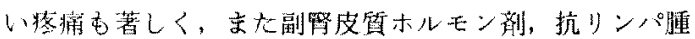

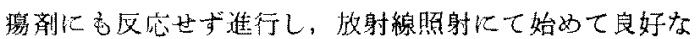
反応がみられたとこるなど共邂の histiocyteによる肉芽 睡病变があったと考光られる。

喉頭の雨三の生検化拘らす組織診断がなされなかった ことは謎であるが，淮行性舆烄痐の中に含まれる悪性細

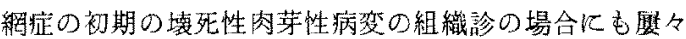
経験されることと同様の特徵と考无られる。

このような鼻にみられる悪性細絧症の一部には，今回 の症例と问様今日の組織猃では atypical histiocyteより なる湎性組織球症上されるる場会が少なからず含まれて

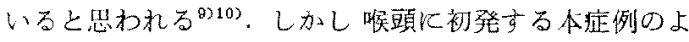

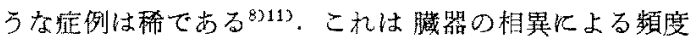
の差加上思われる．いすれれにして手組織球系の疾患の初

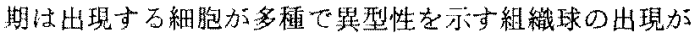
みられず一見次症を思わせる状態にあることは注意する

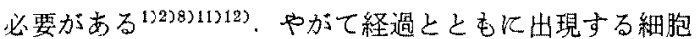
は monotonous に增殖し腫癔的性格を示してくる.

本聇のような病態に対する病名に関しては Scottと Robb-Smith ${ }^{13)}$ の言5 histiocytic medullary reticulosis (HMR) という表現が当るが，1966年 Rappaport ${ }^{14)}$ は histiocytosis 3 つ 飞分類し neoplastic であり買型性 を示す histiocyte の系統的に増殖する状態を malignant histiocytosis とし HMR もこれに含まれるとした。さ bK Warnke ${ }^{15)}$ 委29例 0 malignant histiocytosis 告し HMR との関係につき Rappaport の説を支持し t.

いたずらに分類法を变えることは混舌をまねくのみで 意味がないが，進行性覺壊疽の一部や本症例のよう飞堎 死性肉芽性病变が進行するに拘らず組織彰が上記のよう に難しく、リンパ節の腫脹が末期までみられない疾患の 特徴は，主役を演ずる細胞の origin 関係していると 考えられ ${ }^{16)}$ ，その特翼性を示す適当な表現が与えられた 方が疾患の理解に誤りが生じないと考える。

近年リンパ球の機能が明らかになり悪性りンパ踵もり 
ンパ球の機能を考虑した Lukes $5^{1718)}$ の新しい分類が 用いられてきているが，組織球儿関しても網内系の紐胞 と機能的に翼なるとの報告がある。

Furth $b^{193}$ は Aschoff (1924) 加真食能をむつとした RES 系は phagocytic な機能をすつ1つの系としては邀 当でなく，むしろ Metchinikoff(1892) の胆えた Macrophage を1つの系と考えた方がよいと述でている。

Furth は生体の phagocytic cell は好中球など polymorphonuclear phagocyte $\mathcal{L}$ mononuclear phagocyte に分けられるとし, phagocytic な機能はRES系よりる mononuclear phagocyte につよいことより貪食能をも った系として MPS (mononuclear phagocyte system) を考える方が合理的であると主㷌する。

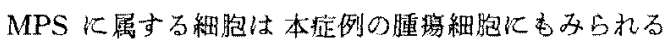
ように蕒食能がつよくエステラーゼ染色（ $\alpha$ ーナフチル アセテイト法， $\alpha$ ナフチルブチレイト法）にて活性が認 められる。これはリンパ球由来の細胞にはみられない特 徽である(別表).

MHの発症が局所か全身的か後述の上うな間題がある ところである。

本症例の場合，偶然加もしれないが発淀の2-3力月 前に右下顎から右頸部にかけゴルフクラブによる打撲を

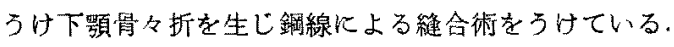

その折の衝整加喉頭の肉荤北成に関与したことも考え られる。しかし殆んど同時に舅閉も訴えており多中心性 の発病とも思わ机る。末期に腦壁，背部，大腿部など の皮下に可動性の腫瘤を形成し，その一部の生検にて atypical histiocyte の浸潤よりなる睡瘤と決定できたが, 同じ頃に刍頭部にみられた肉芽性病变の組織診ではやは non specific granulation であった.

非特異的度肉芽形成の封点と atypical histiocyte の浸 潤し，monotonous な变化がみられる時閶的関係は全身 的に同一ではなく臟器により違うと考えられる。

本症例は剖検出来なかったが末期に白血球減少，肝嘰 能低下がみられたことは骨面や朋への atypical histiocytc の白血病様浸潤が括こったことが推測される。

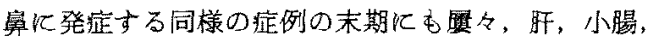

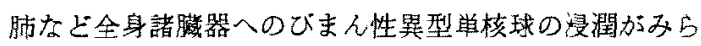
れる(12)8)11)18)20321)22)23224(25)26327328).

malignant histiocytosis 病零がどのようにして全身 に拡がるか対しては次のようなことが考えられる。

(1) 局所病変が primary で全身の病変は転移である.

(2) 多中心性に打こる。
(3) 出現する atypical histiocyte $の$ origin $の$ 骨骾の stem cell の変化が最初飞执こり，その一部が上気道で まず炎症性肉芽を次いで全身性にも同し病変をかこす。 つまり等髄の stem cell が primary の病变部位でする。 本怔例の場合は前述のごとく(1)加(2)が考えられるが， 皃にみられる MHではこの時間的関係が極端に短かい場 合あるいは激症性の前駆期の殆んどない場合もあり， このような場合の病热は局所より生したよいうより(3)の よろなことが起り偶然上気道病变が先行したようにも思 われる。

MHに関する集計報告は比較的少ない。

Warnke $b^{15)}$ (1975) は29例の malignant histiocytosis の集計を行ない，発症年桻は1藏から71藏，平均 31 藏，男女比は 2.2:1 で男性に多いと述べている。

Warnke らの集計による初発症状, 理学所見, 検查成 績を別表に示す（表 $2 ， 3 ， 4$ ）.

これらの特徴と鼻を含む上気道に発症する MHとはい さき加基なる点むある。

最も大きな相堡点は上気道の場合は末期までリンパ節

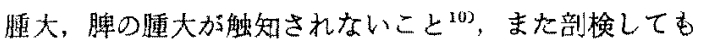
余り腫大していないことである。

発熱はいずれの場合古殆んど全例に認められる症状で あるが，上気道の場合は本症を含め, 初期には発熱が られない場合屯少なくない。

表 2

Malignant histiocytosis の初発症状 (Warnke 1975)

\begin{tabular}{|c|c|c|c|}
\hline \multicolumn{3}{|c|}{ 初発症状 } & 症例数 (29例) \\
\hline 発 & & 熱 & 21 \\
\hline \multicolumn{3}{|c|}{ リンパ節腫大 } & 15 \\
\hline 全 & 身 & 意 & 10 \\
\hline 体 & 重 & 少 & 5 \\
\hline 発 & & 汗 & 4 \\
\hline 胸 & 部 & 痛 & 3 \\
\hline 皮 & & 疮 & 3 \\
\hline 背 & 部 & 瘦 & 1 \\
\hline & 組織䐎 & 彤成 & 1 \\
\hline
\end{tabular}




\section{表 3}

Malignant histiocytosis D理学所晃 (Warnke 1975)

(29唗例)

\begin{tabular}{|c|c|c|}
\hline 理学所見 & 初 期 & 経過中 \\
\hline 体温上昇 & 22 & 4 \\
\hline リンパ節腫大 & & \\
\hline 局 所 & 17 & 1 \\
\hline 全 身 & 4 & 5 \\
\hline 脾 の 腫 大 & 11 & 10 \\
\hline 肝 $\sigma$ 嗹 大 & 12 & 10 \\
\hline 黄 & 2 & 6 \\
\hline 軟部組織腫瘤形成 & 2 & 3 \\
\hline 皮 虞 の 結 節 & 2 & 2 \\
\hline 肋 膜 浸 出 液 & 1 & 3 \\
\hline
\end{tabular}

表 4

Malignant histiocytosis の険疽成績 (Warnke 1975)

(29症例)

\begin{tabular}{|c|c|c|}
\hline 榙 査 成 䊗 & 初期 & 経過中 \\
\hline 血 $(H t .15-35 \%)$ & 11 & 8 \\
\hline 白血球隇少 $\left(1900-4700 / \mathrm{mm}^{3}\right)$ & 9 & 3 \\
\hline 白血球撸加 $\left(33.000-70.000 / \mathrm{mm}^{3}\right)$ & 3 & \\
\hline 血小板娍少 $\left(12.000-140.000 / \mathrm{mm}^{3}\right)$ & 6 & 5 \\
\hline ビリルビン伹症 $(1.7-30.0 \mathrm{mg} / 100 \mathrm{ml})$ & 2 & 4 \\
\hline 末捎血組轿球症 & 0 & 2 \\
\hline クームス陽性 & 1 & 0 \\
\hline
\end{tabular}

盆血や白血球数の增多市るいは減少など末梢血の変化 初期に洁族んどみられない。

予俊炕関しては Warnke らの場合 follow 出来た 21 例の生存期間は 1 力月から8 年, 平均 6 力月である。

一方 Eichel らの鼻に原発するリン八腫堭に関する報

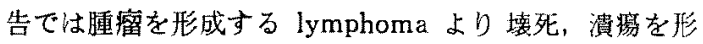

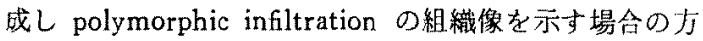
が予娞がよいと述へてている。

自験例の場合， $\mathrm{MH}$ と診断された15例中13例が発症後 4 力月から5 年 5 力月の経過で死しした（平均約 2 年）.

病理竞断の基湐の相造加関係するので一概には言えな
いが, malignant histiacytosis の予後は極めて悪い上考 える、その原风は MHが全身性の病变をきたすことによ るが，予後を照くしている别の因子として初期病变の組

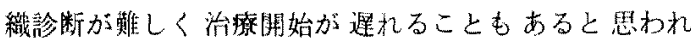
る.

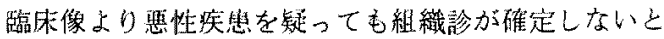
き治瘵は副作用を考䍐して控え目になり勝ちである。本

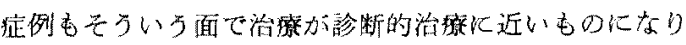
徹底的に治療することが出来なかったことを热めざるを 得ない，組織診が不充分古段陆で徽底した治亦が詐され るのは豊䈏な臨床経駿に基づく場合である

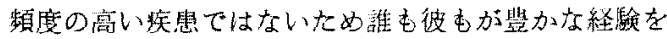
もっているとは言觉ない，本症例のような喉頭化原発す るような MHの報告梅めて少なく，同様の桸な症例委

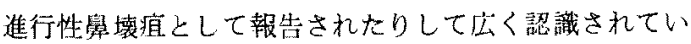
ないよらと思われる。

骨飞限らず polymorphic infiltration を示す肉芽性病 变で䘫死化が進行するときは malignant histiocytosis 初期斿变である可能性を考えて检直計画を行なる人きで ある。

このような龍断手技上の問題とは別に今1つ予後を琹 くしている因子は白血病様の漫潤形式をとる組織球系の 瑟性疾患以对する治療方制が確立されていないことれあ 吕*

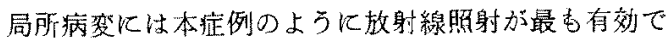

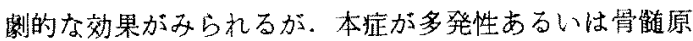
発性之洘えた場合あるいは全身に搪がった段階では化学 潦法が必要である，化学療法は抗リンパ脽瑒剂，抗白直

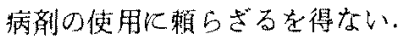

副筒皮質ホルモン剂やオンコビン，エンドキサンなど

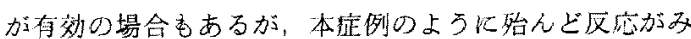
られない場合もある。このような場合，多剂併用汃大量 投与古検討される必要がある。

新しい薬物が得られるまで早期診断上强化療法。維持 療法，補充䝤法に上り，より上い子後の確立への努力を する必要がる。

$$
\text { ま と }
$$

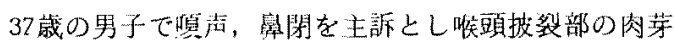
形成初期所胃とした malignant histiocytosis $の 一$ 症 例を報告した。

発祉 1 年間は局所病変の生検は炎拝像であったが，乙

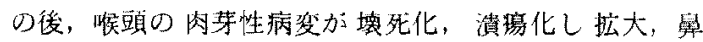




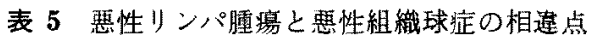

\begin{tabular}{|c|c|c|}
\hline & 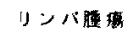 & malignant histiocytosis \\
\hline 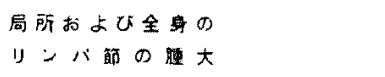 & $(+)$ & $(-)$ \\
\hline 带症部位 & リンパ籍 & non lymph node area \\
\hline 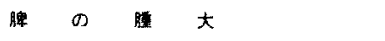 & $(+),(-)$ & 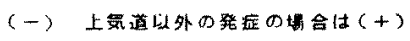 \\
\hline 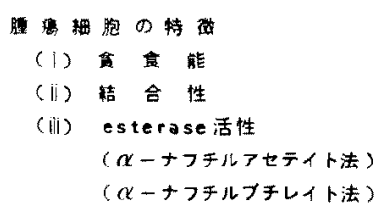 & $\begin{array}{l}(-) \\
(+) \\
(-)\end{array}$ & $\begin{array}{c}(+) \\
(-) \text { 時に(+) } \\
(+) \sim(+)\end{array}$ \\
\hline 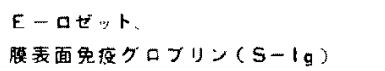 & $(+),(-)$ & $(-)$ \\
\hline
\end{tabular}

部，胸壁皮下，大腿部などに atypical histiocyte が核潤 L, 発症 2 年目江黄底, 白血球減少，発熱，出血倾向を きたし，口腔よりの出血にて死亡した，

绝頭拉よび鼻化発症する malignant histiocytosis は

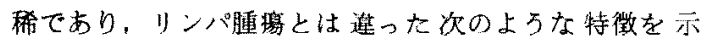
t.

(1) non lymph node area $儿$ 资症性肉芽として発症 する。

(2) 潮次, 演湟を形成し発效, 疼痛を伴う。

(3) 末期まで局所括よび全身の表在りンバ節の雨大が みられない。また他の部位に発症する malignant histiocytosis と避って，脾の腫大傾向が少ない，

(4)組織診は初期はリンパ球, 形質細胞など炎症細胞 の浸潤がつよく atypical monocyte は散在性にしか認め られないが, 漸次 monotonous な病变飞变化する.

(5)腫晹細胞は会食能があり，捺印標本で腫㻛細胞の esterase 活性は陽性を示寸。

\section{参 考 文献}

1) Fechner $R E$ and $D W$ Lamppin: Midline Malignant Reticulosis - a clinicopathologic Entity. Arch Otolaryngol 95: 467-476, 1972.

2) Eichel $B S$ and $E G$ Harrison Jr et al: Primary Lymphoma of the Nose including a Relationship to lethal Midline Granuloma. Amer. J of Surgery 112: $597-605,1966$.
3）渡部泰夫 他：死の忶㷌をとった路悪性肉芽腫4例。 日耳舆 79: 36-49，1976。

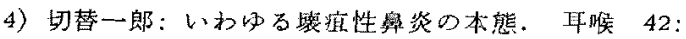
783-791, 1970.

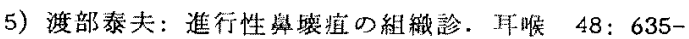
$643,1976$.

6）佐藤武男：喉頭废。金原出版 東京 1972 .

7) Ferlito A: Histiocytic tumors of the larynx a clinicopathological study with review of the literature. Cancer, 42: 611-622, 1978.

8) Eichel $B S$ and TE Mabery: The enigma of the lethal midline granuloma. The Laryngoscope, 78: 1367-1386, 1968.

9) Soule $E H$ and $P$ Enriquez: Atypical fibrous histiocytoma, malignant fibrous histiocytoma, malignant histiocytoma and epitheloid sarcoma. - a comparative study of 65 tumors. Cancer, 30: 128-143, 1972

10）渡部泰夫，青笹克之：上気道化みられる malignant histiocytosis. 日本医事新報 2870：37-40，1979.

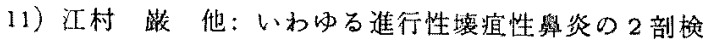
例一之の鑑别点之覀性勫網症からの梌討 日本網 内系学会㝇 16:183-190, 1976.

12）青笹克之, 宇多弘次 他: Malignant histiocytosis の 1 剖検例 蹦床血液 20: 4，424-430，1972.

13) Scott $R B$ and Robb-Smith AHT: Histiocytic 
medullary reticulosis. Lancet, 2: 194-198, 1939.

14) Rappaport $H$ : Tumors of the hematopoietic system. Atlas of Tumor Pathology. sect $\mathbb{I l}$ fasc. 8. AFIP Washington, D. C., 1966.

15) Warnke $K A, H K i m$ and $R F$ Dorfman: Malignant histiocytosis. (Histiocytic medullary reticulosis) - clinicopathologic study of 29 cases. Cancer, 35: 215-230, 1975.

16)石井善一郎他: 細网肉腫の病理学的特異性なら びにその瑟性肉芽腫との接点について。耳 18 : $151-154,1972$.

17) Lukes $R J$ et al: Immunologic characterization of human malignant lymphoma. Cancer, 34: 1488-1503, 1974.

18) Lukes $R J$ et al: New approaches to the classification of the lymphoma. Br J. Cancer, 31: Suppl. II , 1-28, 1975.

19) Furth $R V$ : The mononuclear phagocyte. Blackwell, London, 1970.

20) Walton $E W$ : Reticulo-endothelial sarcoma arising in the nose and palate (granuloma gangrenescens) J. Clini. Path., 13: 279-286, 1960.

21) Kassel $S H$ et al: Midline malignant reticulosis (so-called lethal midline granuloma) Cancer, 23: $920-935,1969$.

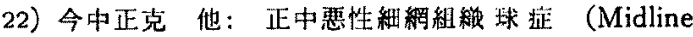
Malignant Reticulohistiocytosis) 一いわゆる進行

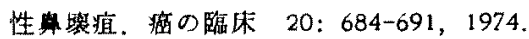

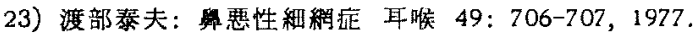

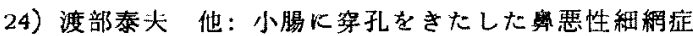

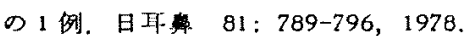

25) Fu $Y S$ and KH Perzin: Nonepithelial tumors of the nasal cavity, paranasal sinuses and nasopharynx. A Clinicopathologic Study. X. Malignant Lymphomas. Cancer, 43: 611-621, 1979.

26）渡部泰夫：血管炎者伴 5 病熊の䠰休之病理一進行

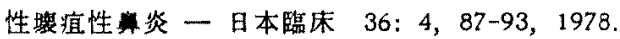

27）中沼安二他: Midline malignant reticulosis 01 剖揄例。蹦床血液 $18 ： 10 ， 1226-1232 ， 1977$ 。

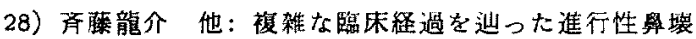
瘨の1剖检例。日本舆副身腔学会誌 $16: 133-134$, 1977.

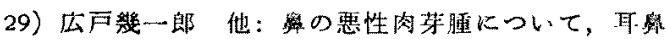
19: 349-360, 1973.

本論交の要旨は第 3 回頭颧部腫痬学会（昭和54年6月 29日，小田原市）に扎いて発表した。

（原稿受付 昭和54.9.27日）

別刷請求先 T558 大阪市住吉区万代東 4-25 大阪府立俩院耳學咽喉科渡部泰夫 